\title{
Treatment of Oral Piercing Complications in Periodontal Tissues with the use of Enamel Matrix
}

\author{
Leonidas Batas* and Lazaros Tsalikis \\ Department of Periodontology, Aristotle University of Thessaloniki, Greece
}

Received: March 07,2018; Published: March 16, 2018

*Corresponding author: Leonidas Batas, Department of Periodontology, School of Dentistry, Aristotle University of Thessaloniki, Thessaloniki, Greece, Email: tsalikis@dent.auth.gr

\begin{abstract}
In the last decade, body piercing has become increasingly fashionable especially among young adults. The growing trend of oral piercing must be a concern to dental professionals because of the risks and complications in the oral cavity. Oral piercings, such as tongue and lip piercing, can cause several complications such as hemorrhage, pain, swelling, lingual nerve damage, gingival recession, infection, periodontal distraction and fractured teeth. The purpose of this paper is to present case reports and methods of treating the complications of tongue and lip piercing that appeared to the periodontal tissues on the lingual and buccal sites of the lower incisors. In all cases EMD (Emdogain $®$ ) was used and the oral piercing was removed. All cases showed reduction of the pocket depth, gain in clinical attachment level and significant reduction of gingival recession. As a conclusion the use of EMD may be a treatment of choice in patients that had periodontal damage after oral piercing and these results seems to be reproducible.
\end{abstract}

Abbrevations: PD: Pocket Depth; CAL: Clinical Attachment Level; EMD: Enamel Matrix Derivative

\section{Introduction}
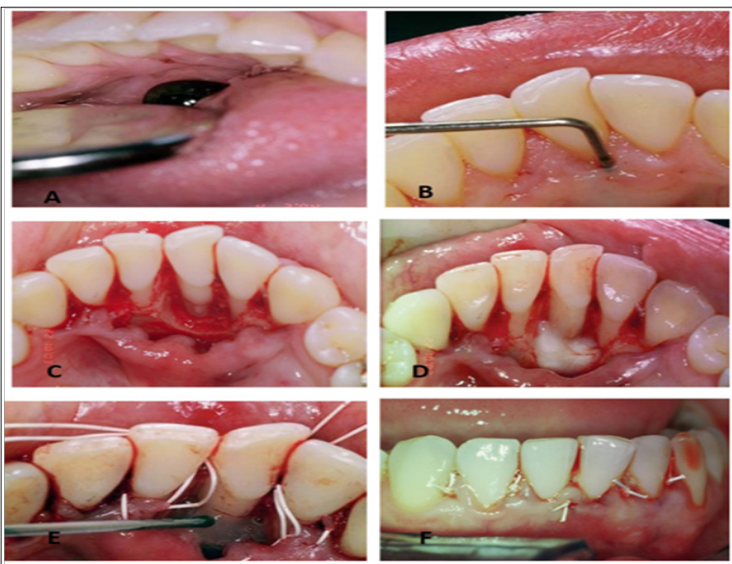

Figure 1: A: The lower metal ball of the tongue piercing came in contact with area where the destruction of the lingual alveolar plate was present.

B: $8 \mathrm{~mm}$ pocket depth (PD) on the lingual surface of \# 41 .

C: Full thickness flaps raised, Lingual plate was missing.

D: EDTA was cautiously placed on the root surface for two minutes.

E: Emdogain ${ }^{\circledR}$ was placed on the surface of the root of \# 41.

F: Flaps were sutured back.
A 26-year-old woman came in our office complaining of gum bleeding and swelling. Intraoral examination revealed a tongue piercing and also gum swelling in the lingual area of the lower central incisors and an $8 \mathrm{~mm}$ pocket depth (PD) on the lingual surface of \# 41 (Figure 1). Radiographic examination showed distraction of the lingual plate in the area of \# 31 and \# 41. It was also noted that the lower metal ball of the tongue piercing came in contact with area where the destruction of the lingual alveolar plate was present (Figure 1). After explaining to the patient the problems that where created due to the tongue piercing, it was advised to her to remove the tongue jewel in order to begin periodontal treatment in the area. The goal of the treatment was to reduce inflammation and increase the clinical attachment level (CAL).

Conservative periodontal treatment (scaling and root planning) was performed. After one month there was reduction of inflammation but no reduction of PD was noted. At the surgical treatment a full thickness flap was performed at the area of \# 31 41. Granulation tissue and residual calculus were removed from the area. Then, EDTA was cautiously placed on the root surface for two minutes, which was then removed by irrigating saline at the site (Figure 1). After the irrigation the root was dried and then carefully Emdogain was placed on the surface of the root of \# 41 (Figure 1). Finally, the flap was sutured back using resorbable sutures 
(Figure1). The patient was given post-operative instructions and medication was administered (amoxicillin 500 mg every 8 hours, ibuprofen every 6 hours and chlorhexidine $0.12 \%$ ). Sutures were removed after 2 weeks. After 6 months, a $6 \mathrm{~mm}$ reduction of the pocket depth, increased CAL and no inflammation was observed in the area (Figure 2). Comparison of radiographs before and after surgical treatment confirms the results (Figure 2).
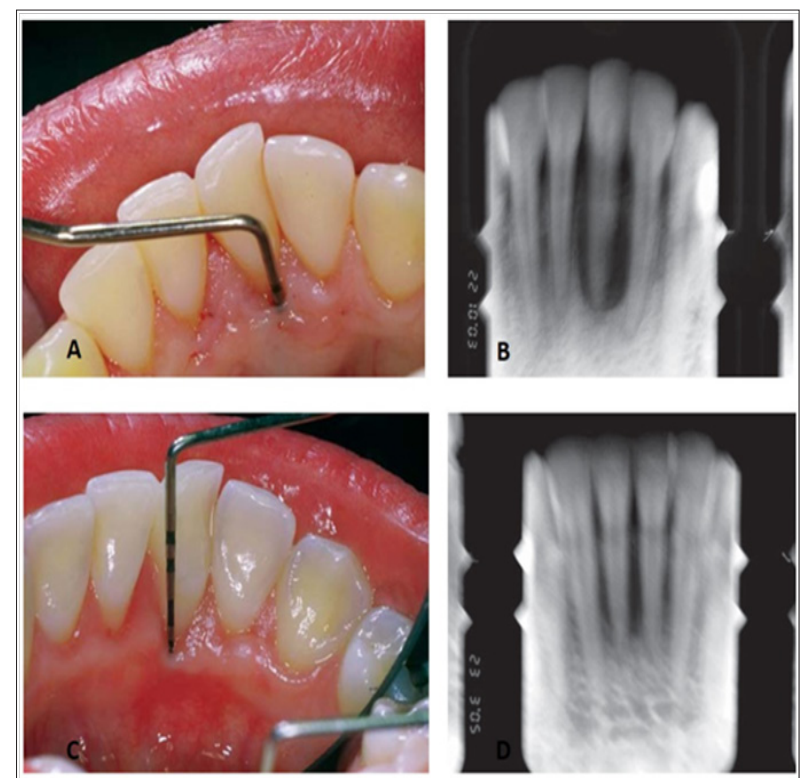

Figure 2: Clinical and radiographic findings before treatment $(A, B)$ and 2 years after treatment $(C, D)$.

\section{Case Report 2}

A 21-year-old woman with a tongue piercing came in our clinic. The chief complain was bleeding gums and pain at her lower frond teeth. After intra oral examination, inflammation, bleeding on probing, deep pocket depth and extensive recession was observed at the area of \# 41 (Figure 3). X-ray examination showed destruction of lingual plate in area 32-42 (Figure 3). And in this case also, the lower metal ball of the tongue piercing came in contact with area where the destruction of the lingual alveolar plate was present. Again it was advised to the patient to remove the tongue jewel in order to begin periodontal treatment in the area. Conservative periodontal treatment (scaling and root planning) was performed.
At the surgical treatment, a partial thickness flap was applied at the lingual surface of the dental papilla, following the guide lines the double papilla technique, and then full thickness flaps were performed at the area of \# 31 - 41.Granulation tissue and residual calculus were removed from the area. Then, EDTA was cautiously placed on the root surface for two minutes, which was then removed by irrigating saline at the site. After the irrigation the root was dried and then carefully Emdogain was placed on the surface of the root (Figure 3). The two papillae were sutured together and then the flap was sutured more coronally using resorbable sutures (Figure 3). Sutures were removed after 2 weeks. After 6 months, a $6 \mathrm{~mm}$ reduction of the pocket depth and recession was observed at the area and no inflammation was observed in the area (Figure 4).

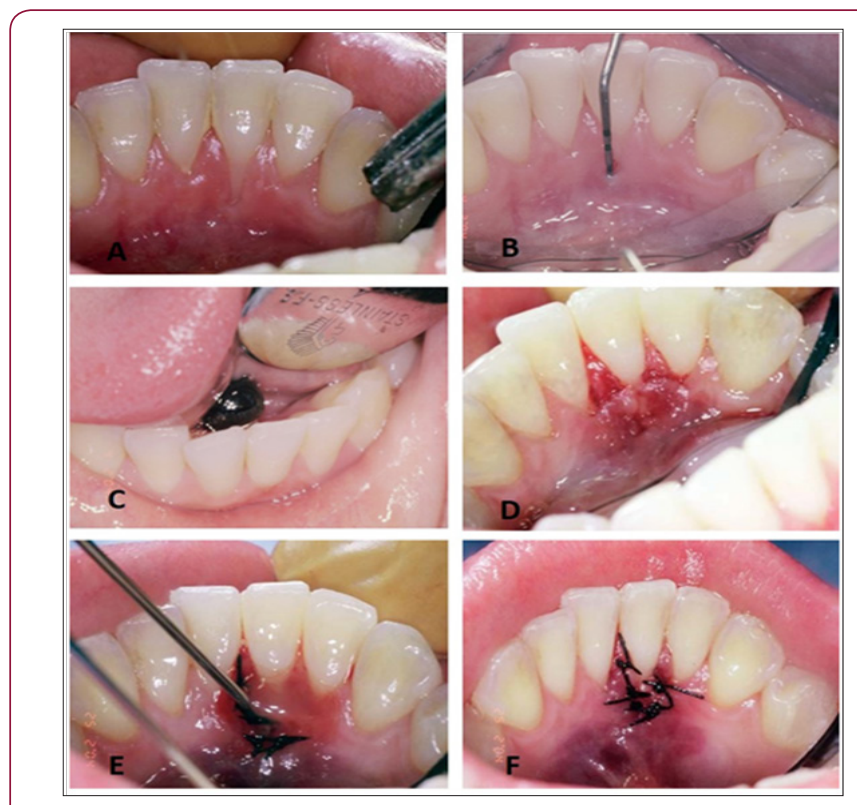

Figure 3: A: Lingual recession \#41

B: Deep pocket depth. Loss of clinical attachment level (CAL)

C: The lower metal ball of the tongue piercing came in contact with area where the recession was present.

D: Split thickness flaps were raised following the double papilla technique. The two papillae were sutured together. E: Emdogain ${ }^{\circledR}$ was placed on the surface of the root of \# 41.

F: Flaps were sutured coronally.
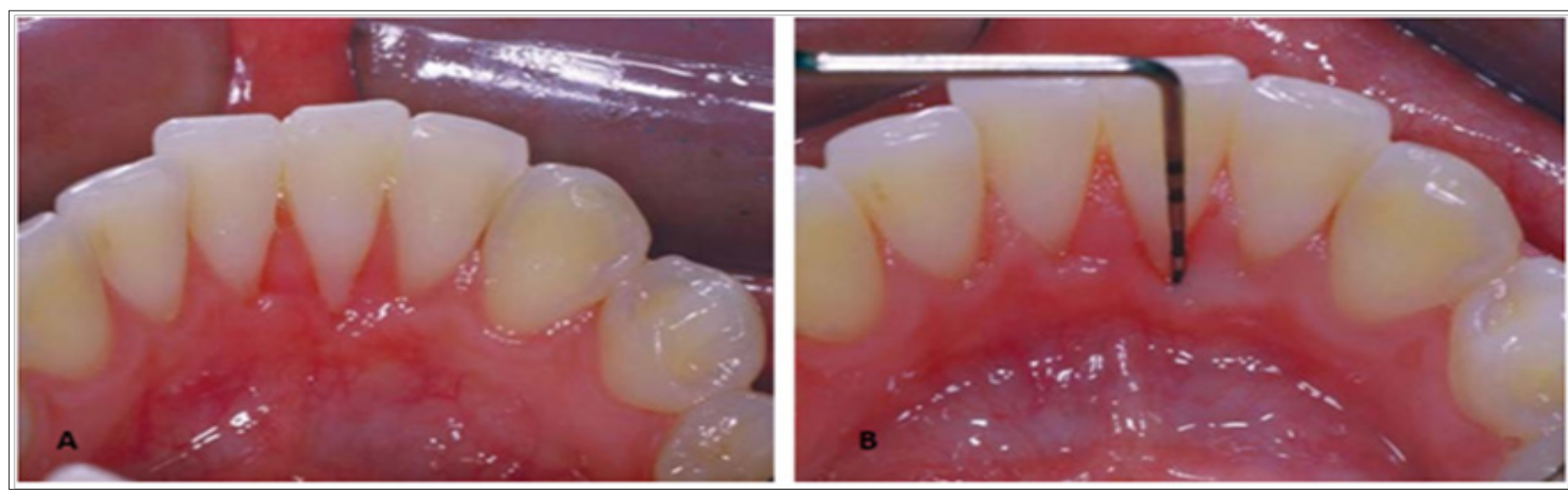

Figure 4: Reduction of recession and Probing depths were noticed 6 months after surgery. 


\section{Case Report 3}

The third incident concerns a 29-year-old woman. The chief complaint was that she noticed a very big recession at the buccal area of the lower incisors. During the clinical examination a $8 \mathrm{~mm}$ gum recession was noticed at \# 31 (Figure 4) and also it was noted that patient had a lip piercing and the metal segment was in contact with the buccal plate were the recession was present. It was advised to the patient to remove the lip jewel in order to begin periodontal treatment in the area. The aim of the treatment was to reduce the recession and improve the prognosis of the tooth. It was decided to perform a connective tissue graft surgery at the site of \#31. Connective tissue was harvested from the palate (Figure 4). A split thickness flap was raised at the site \# 31. Then the root was conditioned with EDTA for 2 minutes. The connective tissue was then sutured in place covering the root of \#31 (Figure 4). Emdogain was carefully then placed on the root surface and the flap were sutured back coronally covering the connective tissue graft with resorbable sutures (Figure 4). The patient received post-operative instructions. Sutures were removed after 2 weeks. After 6 months, reduction of recession was observed. 4 years post operatively the results remained the same (Figure 5).

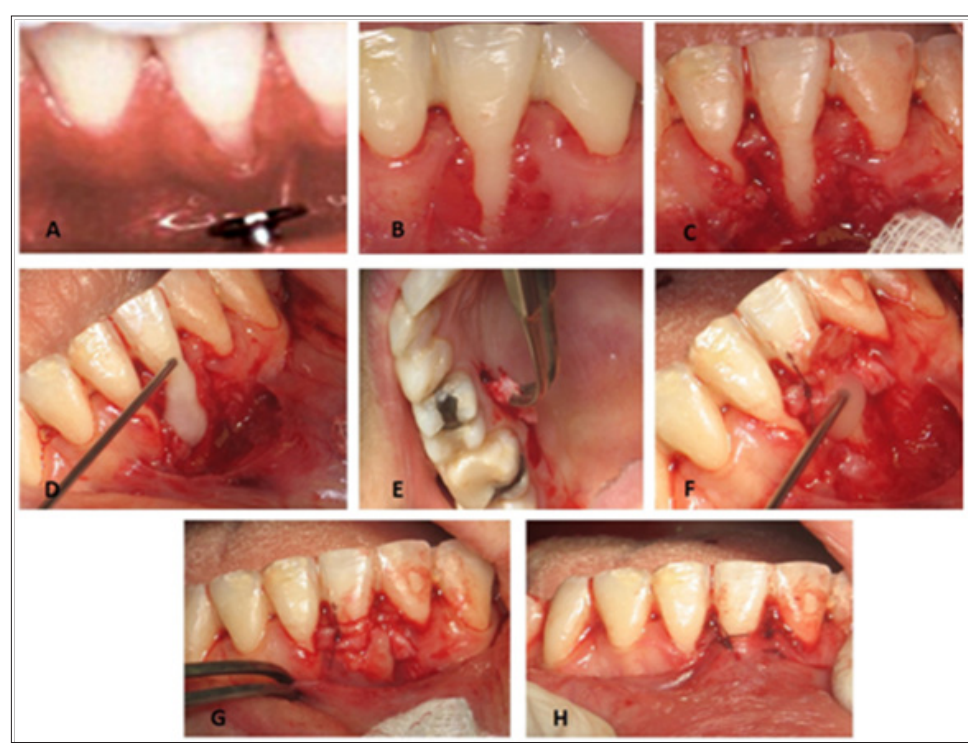

Figure 5: A: The metal segment of the lip piercing came in contact with buccal plate at the area of 31.

B: Recession was noticed at the site of \#31.

C: Partial thickness flaps were raised.

D: Root was conditioned with EDTA.

E: Connective tissue graft was haversed.

F: Emdogain ${ }^{\circledR}$ was placed on the root surface of \#31

$\mathrm{G}$ : Connective tissue graft covered the root of \#31.

$\mathrm{H}$ : Flaps were sutured coronally covering the connective tissue graft.
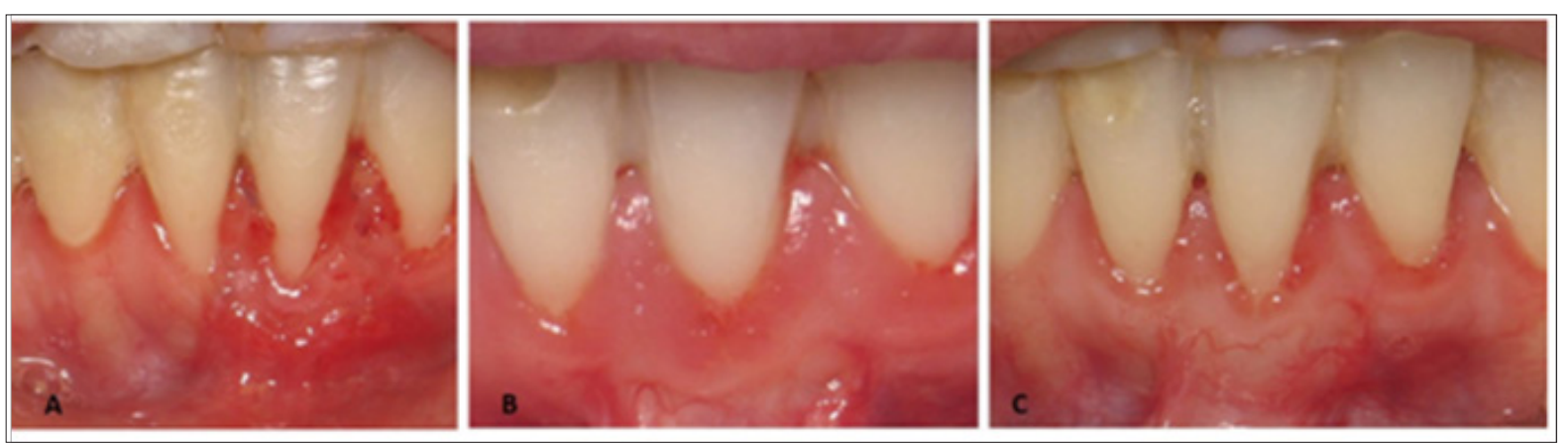

Figure 6: A: 1 month after surgery, B: 6 months after surgery, C: 4 years after surgery.

\section{Discussion}

Oral piercing is an increasing social phenomenon. Therefore, dentists should be familiar with the consequences that this phenomenon may cause on dental and periodontal tissues. It is characteristic that in a survey conducted in Lancashire, in a sample of 106 clinical general dentists, $96.9 \%$ replied that patients with oral piercing, have come to their clinic13. In the literature it has been shown that there is a loss of attachment and bone support in the lower incisors, as well as severe ulceration and recession in the region [16-31]. In other cases, oral piercing patients caused fractures of teeth [32-35]. Also patients with trigeminal neuralgia are reported after tongue piercing [36]. There are also reports 
in which the perforation of the tongue has led to more serious complications, such as airway obstruction and dyspnea,[36], lingual problem [37,38], cerebral abscess due to streptococcus viridans infection [39,40], Ludwig [41-43], microbial endocarditis after Neisseria mucosa [43-45] infection, septicemia after prolonged bleeding [46], hepatitis [47], tetanus [48], chewing and chewing difficulties $[49,50]$, fractured teeth $[51,52]$ and allergic reactions due to foreign body reaction.

Generally when a patient with oral piercing arrives our clinic, it must be explained to him/her all the risks and injuries that may occur, and try to convince that the best treatment is to remove it. When periodontal tissue lesions are present, the use of EMD (Emdogain) seems to be a reliable solution for reducing pocket depths, increasing clinical attachment levels and reducing inflammation. Enamel matrix derivative (EMD) (EmdogainStraumann, Basel, Switzerland) is the most widely studied commercially available bioactive agent. It is derived from the tooth pouches of unerupted porcine teeth and is composed of amelogenins and enzyme components. The biological rationale for the use of EMD is to recapitulate developmental mechanisms whereby enamel matrix proteins are proposed to play a critical role in stimulating cementogenesis. The role of enamel proteins in periodontal ligament formation is supported by their presence in initial cementum formation during normal development of tooth attachment $[53,54]$. The major $(>95 \%)$ constituent of EMD is amelogenins, a family of hydrophobic proteins derived from a single gene by alternative splicing and controlled post-secretory processing. The amelogenins are known to self-assemble into supramolecular aggregates that form an insoluble extracellular matrix [55] with high affinity for hydroxyl apatite and collagens [56]. When applied to denuded root surfaces, amelogenins therefore precipitates to form a stable extracellular matrix with a hydrophobic surface with potential for supporting interactions with cells in adjacent tissues. It should be noted that when EMD is used, for a period of six months from the surgical procedure it is important not to use periodontal probe in the area because it prevents proper healing of the area. Any evaluation of the result must be made after the end of the six months.

\section{Conclusion}

Oral piercings are a growing trend and dental care professionals are increasingly likely to treat a patient with at least one oral piercing. Having the knowledge to provide quality care to such patients, to educate the patient about the complications of oral piercings prior to the procedure and to recognize problems and appropriately treat or refer the patient is important in our evermore-global society. From three case reports that was presented it was indicated that the use of EMD seems to have good and reproducible results in treating periodontal complications after oral piercing. Certainly, further research is needed on this.

\section{References}

1. Küstner EC, Travé I, Rengifo S, Carabaño T, Iglesias H, et al. (2003) Appearance and culture: oral pathology associ-ated with certain fashions (tattos, piercings, etc.). Med oral 8(3): 197-206.
2. (2018) American Academy of Pediatric Dentistry. Policy on Intraoral/ Perioral Piercing and Oral Jewelry/Accessories.

3. Holbrook J, Minocha J, Laumann A (2012) Body piercing: complications and prevention of health risks. Am J Clin Dermatol 13(1): 1-17.

4. Pramod RC, Suresh KV, Kadashetti V, Pramod S Ingaleshwar, Sharan J Shetty, et al. (2012) Oral piercing: A risky fashion. J Educ Ethics Dent 2(2): 56-60.

5. Levin L, Zadik Y, Becker T (2005) Oral and dental complications of intraoral piercing. Dent Traumatol 21(6): 341-343.

6. Garcia Pola M, Garcia Martin J, Varela Centelles P, Bilbao Alonso A, Cerero Lapiedra R, et al. (2008) Oral and facial piercing: Associated complications and clinical repercussion. Quintessence International 39(1): 51-59.

7. Escudero Castaño N, Perea García MA, Campo Trapero J, Cano Sánchez, Bascones Martínez (2008) Oral and Perioral Piercing Complications. The Open Dentistry Journal 2: 133-136.

8. De Moor R, De Witte A, Delmé K, De Bruyne M, Homme G (2007) Dental and buccal complications of lip and tongue piercing. Revue belge de Medécine dentaire 62(2): 104-112.

9. Scott P, Baker A, Spencer RJ (2004) Oral piercing and associ- ated complications: Two case reports. Dental Update 31(7): 421-422.

10. Kieser JA, Thomson WM, Koopu P, Quick AN (2005) Oral piercing and oral trauma in a New Zealand sample. Dent Traumatol 21(5): 254-257.

11. Jornet PL, Camacho Alonso F (2006) Oral and dental compli- cations of Intra - oral piercing. Journal of Adolescent Health. 39(5): 767-769.

12. Bassiouny M, Deem L, Deem T (2001) Tongue piercing: a restorative perspective. Quintessence International. 32(6): 477-481.

13. Bagnall S (2011) Oral piercing and dental complications. Vital Winter 9(1): 20-22.

14. Plessas A, Pepelassi E (2012) Dental and periodontal complications of lip and tongue piercing: prevalence and influencing factors. Aust Dent J 57(1): 71-78.

15. Rethman J (2012) Educate patients about oral piercing risks. Dimensions of Dental Hygiene 10(11): 74.

16. Stead LR, Williams JV, Williams AC, Robinson CM (2006) an investigation into the practice of tongue piercing in the South West of England. British dental journal 200(2): 103-107.

17. Chen M, Scully C (1992) Tongue piercing-a new fad in body art. British Dental Journal 172(3): 87.

18. Perkins CS, Meisner J, Harrison JM (1997) A complication of tongue piercing. Br Dent J 182: 147-148.

19. Wittle G, Lamden K (2004) Lip and Tongue piercing: Experiences and views of General Dental Practitioners in South Lancashair. Primary Dental Care 11(3): 92-96.

20. Kapferer I, Benesch T, Gregoric N, Ulm C, Hienz SA (2007) Lip piercing: prevalence of associated gingival recession and contributing factors. A cross-sectional study. J Periodont Res 42(2): 177-183.

21. Shimshon S, Liran L (2008) Gingival recession in young adults: Occurrence, severity, and relationship to past orthodontic treatment and oral piercing. American Journal of Orthodontics and Dentofacial Orthopedics 134(5): 652-656.

22. Chambrone L, Chambrone LA (2003) Gingival recessions caused by lip piercing: case report. Journal of the Canadian Dental Association 69(8): 505-508.

23. Soileau K (2005) Treatment of a mucogingival defect associated with intraoral piercing. Journal of American Dental Association 136(4): 490494. 
24. Pedrinazzi M, Bez C, Lodi G, Carrassi A, Sardella A (2002) Labial piercing resulting in gingival recession. A case series. Journal of Clinical Periodontology 29(10): 961-966.

25. Brooks J, Hooper K, Reynolds M (2003) Formation of mucogingi-val defects associated with intraoral and perioral piercing. Journal of American Dental Association 134(7): 837-843.

26. Choe J, Almas K, Schoor R (2005) Tongue piercing as risk factor to periodontal health. The New York state dental journal 71(5): 40-43.

27. Zadik Y, Sandler V (2007) Periodontal attachment loss due to applying force by tongue piercing. Journal of the California Dental Association 35(8): 550-553.

28. Berenguer G, Forrest A, Horning G, Towle H, Karpinia K (2006) Localised periodontitis as a long - term effect of oral pierc-ing: a case report. Compendium of continuing education in dentistry 27(1): 24-27.

29. Shinohara EH, Horikawa FK, Ruiz MM, Shinohara MT (2007) Tongue piercing: case report of a local complication. Journal of contemporary dental practice 8(1): 83-89.

30. Levin L (2007) Alveolar bone loss and gingival recession due to lip and tongue piercing. New York state dental journal 73(4): 48-50.

31. López - Jornet P, Navarro-Guardiola C, Camacho-Alonso F, VicenteOrtega V, Yánez-Gascon J (2006) Oral and facial piercings: a case series and review of the literature. International Journal of Dermatology 45(7): 805-809.

32. Kapferer I, Hienz S, Ulm C (2008) Labial piercing and localized periodontal destruction-partial periodontal regeneration following periodontal debridement and free gingival graft. Dental Traumatology 24(1): 112-114.

33. Leichter JW, Monteith BD (2006) Prevalence and risk of traumat-ic gingival recession following elective lip piercing. Dental Traumatology 22(1): 7-13.

34. Brooks J, Hooper K, Reynolds M (2003) Formation of mucogingi- val defects associated with intraoral and perioral piercing. Journal of American Dental Association 134(7): 837-843.

35. Choe J, Almas K, Schoor R (2005) Tongue piercing as risk factor to periodontal health. The New York state dental journal 71(5): 40-43.

36. Choe J, Almas K, Schoor R (2005) Tongue piercing as risk factor to periodontal health. The New York state dental journal 71(5): 40-43.

37. Zadik Y, Sandler V (2007) Periodontal attachment loss due to applying force by tongue piercing. Journal of the California Dental Association 35(8): 550-553.

38. Berenguer G, Forrest A, Horning G, Towle H, Karpinia K (2006) Localised periodontitis as a long - term effect of oral pierc-ing: a case report Compendium of continuing education in dentistry 27(1): 24-27.

39. Choe J, Almas K, Schoor R (2005) Tongue piercing as risk factor to periodontal health. The New York state dental journal 71(5): 40-43.

40. Zadik Y, Sandler V (2007) Periodontal attachment loss due to applying force by tongue piercing. Journal of the California Dental Association 35(8): 550-553.

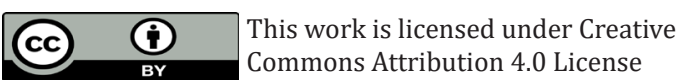

Submission Link: https://biomedres.us/submit-manuscript.php
41. Berenguer G, Forrest A, Horning G, Towle H, Karpinia K (2006) Localised periodontitis as a long - term effect of oral pierc-ing: a case report. Compendium of continuing education in dentistry 27(1): 24-27.

42. Shinohara EH, Horikawa FK, Ruiz MM, Shinohara MT (2007) Tongue piercing: case report of a local complication. Journal of contemporary dental practice 8(1): 83-89.

43. Levin L (2007) Alveolar bone loss and gingival recession due to lip and tongue piercing. New York state dental journal 73(4): 48-50.

44. López-Jornet P, Navarro-Guardiola C, Camacho-Alonso F, Vicente-Ortega V, Yánez-Gascon J (2006) Oral and facial piercings: a case series and review of the literature. International Journal of Dermatology 45(7): 805-809.

45. Kapferer I, Hienz S, Ulm C (2008) Labial piercing and localized periodontal destruction - partial periodontal regeneration following periodontal debridement and free gingival graft. Dental Traumatology 24(1): 112-114.

46. Leichter JW, Monteith BD (2006) Prevalence and risk of traumat- ic gingival recession following elective lip piercing. Dental Traumatology 22(1): 7-13.

47. Brennan M, O'Connell B, O'Sullivan M (2006) Multiple dental fractures following tongue barbell placement: a case report. Dental Traumatology 22(1): 41-43.

48. Cambel A, Moore A, Williams E, Stephens J, Tatakis D (2002) Tongue piercing: impact of time and barbell stem length on lingual gingival recession and tooth chipping. Journal of Periodontology 73(3):289-297.

49. Croll TP (1999) wrecking ball dental fractures: Report of two cases. Quintessence International 30(4):275-277.

50. Fehrenbach MJ (1998) Tongue piercing and potential oral complications. Journal of Dental Hygiene 72(1): 23-25.

51. Botchway C, Kuc I (1998) Tongue piercing and associated tooth fracture. Journal of Canadian Dental Association 64(11): 803-805.

52. Cobb DS, Denehy GE, Vargas MA (1998) Adhesive composite inlays for the restoration of cracked posterior teeth, associ- ated with tongue bar. Practical Periodontics and Aesthetic Dentistry 10(4): 453-460.

53. Hammarström L (1997) Enamel matrix, cementum development and regeneration. J Clin Periodontol 24: 658-668.

54. Spahr A, Hammarström L (1999) Response of dental follicular cells to the exposure of denuded enamel matrix in rat molars. Eur J Oral Sci 107: 360-367.

55. Fincham AG, Moradian-Oldak J, Simmer JP, Sarte P, La EC, et al. (1994) Self-assembly of a recombinant amelogenin protein generates supramolecular structures. J Struct Biol 112: 103-109.

56. Gestrelius S, Andersson C, Johansson AC, Persson E, Brodin A, et al. (1997) Formulation of enamel matrix derivative for surface coating. Kinetics and cell colonization. J Clin Periodontol 24: 678-684.

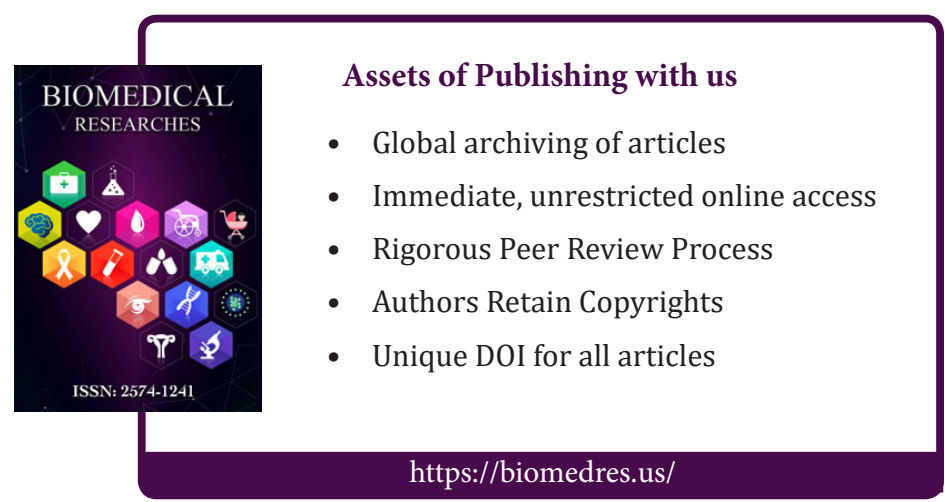

